\title{
Fattening performance of Polish Lowland lambs related to protein level in the diet
}

\author{
J. J. Pająk, Magdalena Slowak and P. Dakowski \\ The Kielanowski Institute of Animal Physiology and Nutrition, Polish Academy of Sciences, \\ 05-110 Jablonna, Poland
}

(Received 9 November 1992; accepted 14 December 1992)

\begin{abstract}
Two experiments were carried out on 212 male Polish Lowland lambs fed a diel containing about $17 \%$ crude protein (group C), according to the Polish feeding standards, or a dict with the crude protein content reduced to $14 \%$ in the DM (group L). The lambs ate approximately $80 \%$ of the DM and 72 to $94 \%$ of the crude protein recommended by Polish standards. Comparison of the amount of protein digestible in the intestine with INRA feeding standards showed that in all of the groups the PDI requirement was exceeded by 5 to 24 per cent. The proportion of total $\mathrm{N}$ passing to the duodenum to $\mathrm{N}$ ingested was similar in groups $\mathrm{C}$ and $\mathrm{L}(91.5 \mathrm{vs} 101.6 \%$, respectively). No significant differences were found in the daily gains of lambs from groups $\mathrm{C}$ ( 237 and $240 \mathrm{~g}$ ) and $\mathrm{L}$ (226 and $238 \mathrm{~g})$, while protein utilization in the $\mathrm{L}$ groups was significantly better $(P \leqslant 0.01)$ than in the $C$ groups ( 675 and $580 \mathrm{vs} 770$ and $662 \mathrm{~g} / \mathrm{kg}$ gain, respectively). The carcass composition of the lambs was similar, with a slightly higher $(P \leqslant 0.05)$ proportion of separable fat in the carcasses of group $\mathrm{L}(16.5 \mathrm{vs} 15.2 \%$ and $16.6 \mathrm{vs} 14.7 \%$ in experiments I and II, respectively), while wool production was somewhat lower in this group than in group $\mathrm{C}$.
\end{abstract}

KEY WORDS: protein level, energy utilization, body composition, Polish Lowland lambs

\section{INTRODUCTION}

The earlier studies carried out at Jabłonna (Jayaprakash, 1984; Żebrowska et al., 1992; Pająk et al., 1992) have shown that Polish Merino lambs fed during fattening period a diet containing $14.5 \%$ crude protein in dry matter showed a similar gain as those receiving a diet containing $16-17 \%$ crude protein, as recommended by Polish feeding standards. Reduction of the protein level in the diet also had no effect on the chemical composition of the empty body or the empty body gain, while protein utilization was improved. Studies of Urbaniak (1986) have also shown that during fattening period Merino lambs have a lower protein requirement than given by Polish standards. Nutritional requirements may vary among lambs of different races, which is associated with, among others, their different growth rates (ARC, 1980; INRA, 1989). Studies similar to 
the previous ones were undertaken to determine the effect of the dietary protein level on the performance of Polish Lowland lambs.

\section{MATERIAL AND METHODS}

Two experiments were carried out on Polish Lowland male lambs weaned at about 70 days of age: experiment I - on 102 and experiment II - on 110 animals. In experiment I, 96 lambs were divided into two groups of 48, given diets $\mathrm{C}$ and $\mathrm{L}$; in experiment II, 106 lambs (single born - 16, twins male -42 and the male from male + female twin - 48) were also divided into two groups, $\mathrm{C}$ and $\mathrm{L}$, of 53 lambs each. The remaining lambs constituted the ,zero" group and were slaughtered at the beginning of fattening to determine the initial empty body composition. Six subgroups were formed within each dietary group. Lambs from the control group were fed a diet containing, according to Polish standards, $16.5 \%$ crude protein $(\mathrm{CP})$ in dry matter (DM), lambs in group $\mathrm{L}$ were given a diet containing $14 \% \mathrm{CP}$ in DM. The lambs were weighed every two weeks in the morning before feeding. The experiment was continued until the lambs reached a weight of $38-40 \mathrm{~kg}$.

The composition of the diets is given in Table 1. The lambs were fed twice daily and feed intake was recorded. Water was freely available. The rations were adjusted every two weeks in experiment $I$ on the basis of the mean weight of the animals in the subgroups. In experiment II the ration was additionally increased

TABLE 1

Composition of the rations (\%)

\begin{tabular}{|c|c|c|c|c|c|}
\hline \multirow[t]{2}{*}{ Experiment } & \multirow[b]{2}{*}{ Group } & \multicolumn{2}{|c|}{ I } & \multicolumn{2}{|c|}{ 11 } \\
\hline & & $\overline{\mathrm{C}}$ & $\mathbf{L}$ & $\mathrm{C}$ & L \\
\hline Meadow hay & & 25.0 & 25.0 & 15.0 & 15.0 \\
\hline Ground oats & & 35.0 & 52.0 & 44.0 & 57.5 \\
\hline Concentrate mixture $\mathrm{CJ}$ & & 40.0 & 23.0 & 41.0 & 27.5 \\
\hline \multicolumn{6}{|l|}{ Composition of $\mathrm{CJ}$ mixture: } \\
\hline wheat bran & & \multicolumn{2}{|c|}{24.0} & \multicolumn{2}{|c|}{30.0} \\
\hline ground wheat & & \multicolumn{2}{|c|}{52.5} & \multicolumn{2}{|c|}{45.0} \\
\hline soya bean oil meal & & \multicolumn{2}{|c|}{20.5} & \multicolumn{2}{|c|}{22.0} \\
\hline calcium carbonate & & \multicolumn{2}{|c|}{0.9} & \multicolumn{2}{|c|}{1.2} \\
\hline sodium chloride & & \multicolumn{2}{|c|}{1.0} & \multicolumn{2}{|c|}{1.0} \\
\hline dicalcium phosphate & & \multirow{2}{*}{\multicolumn{2}{|c|}{0.6}} & \multirow{2}{*}{\multicolumn{2}{|c|}{0.3}} \\
\hline mineral mixture & & & & & \\
\hline „Mikro B-W" & & \multirow{2}{*}{\multicolumn{2}{|c|}{0.5}} & \multicolumn{2}{|c|}{-} \\
\hline vitamin/mineral supplement & & & & & \\
\hline „Polfamix C-starter” & & \multicolumn{2}{|c|}{-} & \multicolumn{2}{|c|}{0.5} \\
\hline
\end{tabular}


on days five and nine after weighing assuming that the mean weight of the animals had increased by 1 or $2 \mathrm{~kg}$, respectively.

Ruminal protein degradation was determined according to Mehrez and Ørskov (1977) on three wethers of a mean liveweight of $70 \mathrm{~kg}$. The effective ruminal degradability (ERD) of DM and protein was calculated according to Ørskov and McDonald (1979) based on a rate of passage $k=0.06$. The PDIN and PDIE contents were calculated based on ruminal protein degradability and INRA coefficients (1989).

The apparent digestibility of organic matter and protein in the rumen, small intestine and whole gastrointestinal tract, as well as rumen fluid $\mathrm{pH}$ and ammonia nitrogen content were determined on 10 rams, 5 each from groups $\mathrm{C}$ and $\mathrm{L}$, fitted with rumen cannulae, simple cannulae to the doudenum and the ileum, as described by Żebrowska et al. (1992). The animals were fed the same rations as used in experiment II.

The morphological and chemical composition of the empty body and protein and fat deposition were determined in experiment $I$ on 6 representative lambs from each group, killed at the end of the fattening period. In experiment II, 8 pairs of twin lambs assigned to $C$ and $L$ groups, were killed.

Slaughter analysis, chemical analysis of the feeds and empty body of the lambs as well as calculation of the energy value of the body weight gains and protein utilization were carried out as described previously by Pająk et al. (1992). Preparation of separable fat for analysis was modified: the fat was placed in sealed polyethylene bags and frozen to a temperature of $-18^{\circ} \mathrm{C}$ for $3-4$ hours and ground twice immediately after removal from the freezer. Metabolizable energy utilization was calculated as the ratio of the amount of energy deposited in the body to the metabolizable energy available for growth, assuming a basal requirement of $418 \mathrm{~kJ} / \mathrm{kg} \mathrm{W}^{3 / 4}$.

The results were subjected to single variable variance analysis.

\section{RESULTS}

The chemical composition of the feed is given in Table 2. In experiment I the ration contained $25 \%$ hay (Table 1); the lambs refused over half of the offered amount, and as effect the protein level in the ingested ration was greater than planned (Table 3). For this reason the proportion of hay in experiment II was reduced to 15 per cent. With the small amount of refusals, the proportion of hay and concentrates ingested by the lambs in both groups and in both experiments were similar (Table 3 ).

The nutritive value of the rations in comparison with recommended allowances according to Polish and INRA feeding standards are given in Table 4. They show that the lambs ate 72 to $94 \%$ of the crude protein recommended by Polish 
TABLE 2

Chemical composition of feeds, effective rumen degradability of DM and protein (\%) and PDIN and PDIE contents (g)

\begin{tabular}{|c|c|c|c|}
\hline Nutrients & $\begin{array}{c}\text { Meadow } \\
\text { hay }\end{array}$ & $\begin{array}{c}\text { Ground } \\
\text { oats }\end{array}$ & $\begin{array}{c}\mathrm{CJ} \\
\text { mixture }\end{array}$ \\
\hline Dry matter & 86.9 & 89.3 & 89.3 \\
\hline Crude ash & 7.1 & 2.7 & 5.5 \\
\hline Crude protein & 10.7 & 9.5 & 21.9 \\
\hline Ether extract & 2.0 & 5.3 & 2.5 \\
\hline Crude fibre & 26.8 & 11.0 & 6.7 \\
\hline$N$-free extractives & 40.3 & 60.8 & 52.7 \\
\hline \multicolumn{4}{|l|}{ Effective ruminal degradability* } \\
\hline dry matter & 44.9 & 70.8 & 72.9 \\
\hline crude protein & 51.1 & 87.5 & 72.8 \\
\hline PDIN & 70 & 58 & 155 \\
\hline PDIE & 82 & 66 & 123 \\
\hline
\end{tabular}

* $\operatorname{EDR}(\mathrm{k}=0.06)$

TABLE 3

Intake of the ration

\begin{tabular}{|c|c|c|c|c|c|}
\hline \multirow[t]{2}{*}{ Experiment } & \multirow[b]{2}{*}{ Group } & \multicolumn{2}{|c|}{ I } & \multicolumn{2}{|c|}{ II } \\
\hline & & $\mathrm{C}$ & $\mathrm{L}$ & $\mathrm{C}$ & $\mathrm{L}$ \\
\hline $\begin{array}{l}\text { In ration: } \\
\text { meadow hay } \\
\text { concentrates }\end{array}$ & $\%$ & $\begin{array}{l}13.8 \\
86.2\end{array}$ & $\begin{array}{l}14.6 \\
85.4\end{array}$ & $\begin{array}{l}13.8 \\
86.2\end{array}$ & $\begin{array}{l}13.9 \\
86.1\end{array}$ \\
\hline $\begin{array}{l}\text { In DM of ration: } \\
\text { crude protein } \\
\text { degradable } \\
\text { non-degradable }\end{array}$ & $\%$ & $\begin{array}{r}17.8 \\
13.5 \\
4.3\end{array}$ & $\begin{array}{r}15.1 \\
11.8 \\
3.3\end{array}$ & $\begin{array}{r}16.2 \\
12.3 \\
3.8\end{array}$ & $\begin{array}{r}14.3 \\
11.2 \\
3.1\end{array}$ \\
\hline $\begin{array}{l}\text { PDIN } \\
\text { PDIE }\end{array}$ & $\mathrm{g}$ & $\begin{array}{l}117 \\
106\end{array}$ & $\begin{array}{l}95 \\
93\end{array}$ & $\begin{array}{l}112 \\
103\end{array}$ & $\begin{array}{l}98 \\
95\end{array}$ \\
\hline $\begin{array}{c}\text { Metabolizabie energy } \\
\text { ME/GE }\end{array}$ & M.J & $\begin{array}{r}10.99 \\
0.58\end{array}$ & $\begin{array}{r}10.66 \\
0.56\end{array}$ & $\begin{array}{r}10.89 \\
0.58\end{array}$ & $\begin{array}{r}10.59 \\
0.56\end{array}$ \\
\hline
\end{tabular}

standards. In all of the groups, the PDI requirements were exceeded by 5 to 24 per cent. The PDIN and PDIE values are given in Table 3; the true protein value of the diet is represented by the smaller of these figures.

The digestibility of the organic matter in the rumen and in the small intestine (Table 5) was similar in groups $\mathrm{C}$ and $\mathrm{L}$, but large differences within group were 
TABLE 4

The nutritive vaiue of the rations in comparison with recommended allowances according to Polish and INRA feeding standards

\begin{tabular}{|c|c|c|c|c|c|}
\hline \multirow[t]{2}{*}{ Experiment } & \multirow[b]{2}{*}{ Group } & \multicolumn{2}{|c|}{ I } & \multicolumn{2}{|c|}{ II } \\
\hline & & $\mathrm{C}$ & $\mathrm{L}$ & $\mathrm{C}$ & $\mathrm{L}$ \\
\hline Provided in ration: & $*$ & & & & \\
\hline dry matter & & 99.1 & 99.6 & 86.1 & 97.7 \\
\hline crude protein & & 106.4 & 91.3 & 87.2 & 79.0 \\
\hline In ration intake: & $*$ & & & & \\
\hline dry matter & & 84.3 & 83.3 & 79.8 & 79.8 \\
\hline crude protein & & 94.3 & 78.8 & 81.0 & 72.1 \\
\hline INRA allowances & $* *$ & & & & \\
\hline PDIN & & 137.4 & $1[0.5$ & 124.9 & 108.5 \\
\hline PDIE & & 124.2 & 107.8 & 114.7 & 105.1 \\
\hline
\end{tabular}

* \% requirement

** \% required PDI

found in group $\mathrm{L}$. The amount of the total $\mathrm{N}$ passing to the duodenum was similar to the amount ingested. Somewhat larger amount of ammonia nitrogen was found in the duodenum and rumen contents (Table 6) of animals from group C. Non-ammonia nitrogen in the duodenum content made up 94.2 and $95.2 \%$ of

TABLE 5

Intake, flow to the duodenum and digestibility of organic matter and nitrogen compounds in the small intestine and entire digestive tract

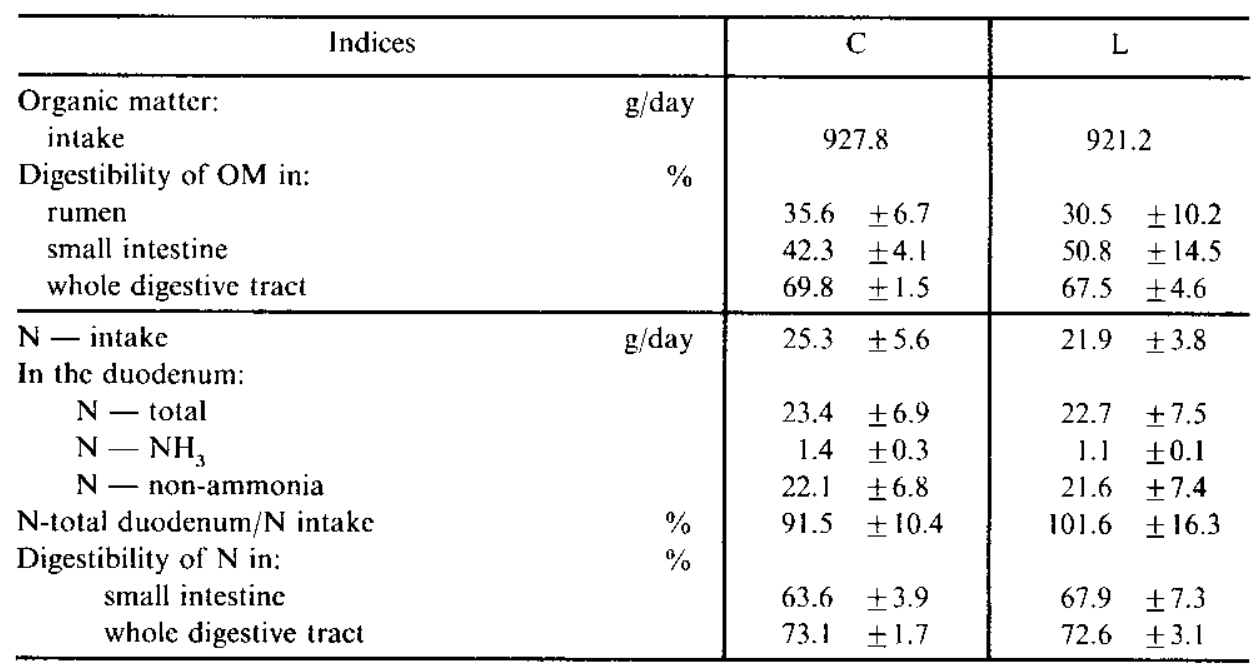

\pm - standard deviation 
TABLE 6

Ruminal N-NH${ }_{3}$ concentration and $\mathrm{pH}$ in lambs two and four hours after feeding

\begin{tabular}{|c|c|c|c|c|c|}
\hline \multicolumn{2}{|c|}{ Time } & \multicolumn{2}{|c|}{$\mathrm{C}$} & \multicolumn{2}{|c|}{$\mathrm{L}$} \\
\hline $\begin{array}{rl} & \mathrm{N}-\mathrm{NH}_{3} \\
2 & \mathrm{hrs} \\
4 & \mathrm{hrs}\end{array}$ & $\mathrm{mM}$ & $\begin{array}{r}12.4 \\
9.2\end{array}$ & $\begin{array}{l} \pm 2.9 \\
\pm 5.5\end{array}$ & $\begin{array}{l}7.1 \\
3.9\end{array}$ & $\begin{array}{r} \pm 4.9 \\
\pm 2.6\end{array}$ \\
\hline $\begin{array}{rl} & \mathrm{pH} \text { rum } \\
2 & \mathrm{hrs} \\
4 & \mathrm{hrs}\end{array}$ & & $\begin{array}{l}6.4 \\
5.8\end{array}$ & $\begin{array}{l} \pm 0.1 \\
\pm 0.3\end{array}$ & $\begin{array}{l}6.0 \\
5.7\end{array}$ & $\begin{array}{l} \pm 0.3 \\
\pm 0.1\end{array}$ \\
\hline
\end{tabular}

the total nitrogen in groups $\mathrm{C}$ and $\mathrm{L}$, respectively. The nitrogen passing to the duodenum was digested in the small intestine by 64 and $68 \%$ in groups $C$ and $L$, respectively. However, the nitrogen digestibility in the whole gastrointestinal tract did not differ between the groups and amounted about 73 per cent. The digestibility of the remaining dietary nutrients was slightly higher in group $C$ than $L$ and equalled for DM 66.7 vs $63.6 \%$, organic matter 69.8 vs $67.5 \%$, for ether extracts 63.8 vs $60.0 \%$, crude fibre 41.0 vs $35.2 \%$ and $\mathrm{N}$-free extractives 76.1 vs $74.4 \%$, respectively.

No significant differences in daily gains were found between lambs from groups $\mathrm{C}$ and $\mathrm{L}$ in experiments I and II (Table 7). No differences were found either in the daily gains of single - born male lambs $(248 \pm 69 \mathrm{~g})$ or as twins

TABLE 7

Liveweight gain and feed utilization

\begin{tabular}{|c|c|c|c|c|c|c|c|c|c|}
\hline \multirow[t]{2}{*}{ Experiment } & \multirow[b]{2}{*}{ Group } & \multicolumn{4}{|c|}{1} & \multicolumn{4}{|c|}{ II } \\
\hline & & \multicolumn{2}{|c|}{ C } & \multicolumn{2}{|r|}{$\mathrm{L}$} & \multicolumn{2}{|c|}{ C } & \multicolumn{2}{|c|}{ L } \\
\hline $\mathrm{n}$ & & \multicolumn{2}{|c|}{48} & \multicolumn{2}{|r|}{48} & \multicolumn{2}{|c|}{53} & \multicolumn{2}{|c|}{53} \\
\hline Initial body weight & $\mathrm{kg}$ & 18.3 & \pm 3.4 & 18.1 & \pm 3.3 & 17.9 & \pm 2.9 & 17.7 & \pm 3.0 \\
\hline Final body weight & $\mathrm{kg}$ & 38.3 & $\pm 2.0^{\mathrm{a}}$ & 36.9 & $\pm 4.8^{\mathrm{b}}$ & 39.3 & \pm 2.0 & 38.9 & \pm 2.5 \\
\hline - grcasy wool & $\mathrm{g}$ & & - & & - & 1360 & \pm 250 & 1300 & \pm 320 \\
\hline Days of fattening & & 84 & \pm 18 & 83 & \pm 18 & 89 & \pm 21 & 89 & \pm 22 \\
\hline Daily liveweight gain & $\mathrm{g}$ & 237 & \pm 40 & 226 & \pm 48 & 240 & \pm 52 & 238 & \pm 46 \\
\hline \multicolumn{10}{|l|}{ Feed utilization: } \\
\hline dry matter & $\mathrm{kg} / \mathrm{kg}$ & & .32 & & 4.48 & & 09 & & .04 \\
\hline crude protein & $\mathrm{g} / \mathrm{kg}$ & & $70^{\wedge}$ & & $75^{\mathrm{B}}$ & & $62^{\mathrm{A}}$ & & $80^{\mathrm{B}}$ \\
\hline metabolizable energy & $\mathrm{MJ} / \mathrm{kg}$ & & 7.5 & & 47.7 & & 4.5 & & 2.8 \\
\hline
\end{tabular}

Statistically significant differences within experiment

ab $-\mathrm{P} \leqslant 0.05$

\pm - standard deviation

$A B-P \leqslant 0.01$ 
(male - twins $237 \pm 45 \mathrm{~g}$ and male + female $240 \pm 46 \mathrm{~g}$ ), regardless of the dietary group. The differences within the same dietary group were also insignificant. With the same mean daily gain of single - born lambs in groups C and L (248g), the gains of twin - male lambs were better in group C than in L ( $243 \mathrm{vs} 231 \mathrm{~g}$ ). Males born with a female had the same daily gains in group $\mathrm{L}$ as single - born lambs (248) while in group C they grew slowly (231g). In both experiments protein utilization was significantly more efficient in subgroups $L(P \leqslant 0.01)$ than in $\mathrm{C}$, differences of $\mathrm{DM}$ and metabolizable energy utilization were nonsignificant. Feed utilization, especially protein, was better in experiment II than I.

TABLE 8

Slaughter performance of lambs

\begin{tabular}{|c|c|c|c|c|c|c|c|c|c|}
\hline \multirow[t]{2}{*}{ Experiment } & \multirow[b]{2}{*}{ roup } & \multicolumn{4}{|c|}{ I } & \multicolumn{4}{|c|}{ II } \\
\hline & & & $\mathrm{C}$ & & L & & $\mathrm{C}$ & & L \\
\hline \multicolumn{2}{|l|}{$\mathbf{n}$} & \multicolumn{2}{|c|}{6} & \multicolumn{2}{|r|}{6} & \multicolumn{2}{|c|}{8} & \multicolumn{2}{|c|}{8} \\
\hline Initial body weight & $\mathrm{kg}$ & 17.4 & $\pm 0.7^{\mathrm{A}}$ & 21.6 & $\pm 1.5^{\mathrm{B}}$ & 16.6 & \pm 1.7 & 16.5 & \pm 2.3 \\
\hline Final body weight & $\mathrm{kg}$ & 36.9 & $\pm 0.9 \mathrm{~A}$ & 38.3 & $\pm 0.7^{\mathrm{B}}$ & 40.1 & \pm 1.4 & 39.3 & \pm 1.6 \\
\hline - greasy wool & $\mathrm{g}$ & 1410 & \pm 370 & 1290 & \pm 250 & 1330 & \pm 170 & 1260 & \pm 110 \\
\hline Days of fattening & & 81 & \pm 16 & 76 & \pm 4 & 98 & \pm 12 & 104 & \pm 16 \\
\hline Daily liveweight gain & $g$ & 249 & \pm 42 & 219 & \pm 24 & 241 & \pm 24 & 223 & \pm 32 \\
\hline Empty body weight: & $\mathrm{kg}$ & & & & & & & & \\
\hline - initial & & 15.1 & \pm 0.5 & 18.4 & \pm 1.3 & 14.1 & \pm 1.4 & 14.1 & \pm 1.8 \\
\hline - final & & 28.8 & \pm 1.1 & 29.9 & \pm 1.2 & 32.1 & \pm 1.3 & 31.4 & \pm 2.0 \\
\hline Daily empty body gain & $\mathrm{g}$ & 167 & $\pm 18^{\mathrm{a}}$ & 148 & $\pm 23^{b}$ & 184 & \pm 18 & 167 & \pm 24 \\
\hline Wool gain & $\mathrm{g}$ & 1110 & \pm 380 & 920 & \pm 260 & 950 & \pm 170 & 890 & \pm 95 \\
\hline Cold carcass & $\mathrm{kg}$ & 14.5 & $\pm 0.7^{\mathrm{a}}$ & 15.6 & $\pm 0.6^{b}$ & 16.2 & \pm 0.8 & 15.8 & \pm 1.1 \\
\hline lean & $\%$ & 55.7 & \pm 1.1 & 56.1 & \pm 3.5 & 58.0 & $\pm 2.7^{\mathrm{a}}$ & 55.3 & $\pm 2.1^{\mathrm{b}}$ \\
\hline separable fat & $\%$ & 15.2 & \pm 2.6 & 16.5 & \pm 2.2 & 14.7 & $\pm 2.0^{\mathrm{a}}$ & 16.6 & $\pm 2.0^{\mathrm{b}}$ \\
\hline bones & $\%$ & 20.7 & \pm 1.3 & 20.2 & \pm 0.5 & 19.9 & \pm 1.2 & 20.2 & \pm 0.8 \\
\hline connected tissue & $\%$ & 7.9 & \pm 1.3 & 6.8 & \pm 0.3 & 7.5 & \pm 0.9 & 7.9 & \pm 1.0 \\
\hline
\end{tabular}

ab $-P \leqslant 0.05$

\pm- standard deviation

$\mathrm{AB}-\mathrm{P} \leqslant 0.01$

The mean daily gain of lambs killed in experiments I and II (Table 8) was similar with the remaining animals (Table 7). In both experiments decreased greasy wool production was found in lambs from groups $\mathrm{L}$ in comparison with C (Table 8). The morphological composition of the carcass of lambs in both experiments was similar, although the percentage of separable fat of lambs in group $\mathrm{L}$ was higher $(\mathrm{P} \leqslant 0.05)$ than those in group $\mathrm{C}$ (Table 8$)$. The chemical 
Chemical composition of the emply body

\begin{tabular}{|c|c|c|c|c|c|c|c|c|c|}
\hline \multirow{2}{*}{\multicolumn{2}{|c|}{ Experiment }} & \multicolumn{4}{|c|}{ I } & \multicolumn{4}{|c|}{ II } \\
\hline & & \multicolumn{2}{|c|}{$\mathrm{C}$} & \multicolumn{2}{|c|}{ L } & \multicolumn{2}{|r|}{$\mathrm{C}$} & \multicolumn{2}{|r|}{$\mathrm{L}$} \\
\hline \multirow{6}{*}{$\begin{array}{l}\text { Empty body weight } \\
\text { dry matter } \\
\text { crude protein } \\
\text { ether extract } \\
\text { crude ash }\end{array}$} & $\mathrm{n}$ & \multicolumn{2}{|c|}{6} & \multicolumn{2}{|c|}{6} & \multicolumn{2}{|r|}{8} & \multicolumn{2}{|r|}{8} \\
\hline & $\mathrm{kg}$ & 28.8 & \pm 1.1 & 29.9 & \pm 1.2 & 32.1 & \pm 1.3 & 31.4 & \pm 2.0 \\
\hline & $\%$ & 36.7 & \pm 1.2 & 37.1 & \pm 2.0 & 36.0 & $\pm 1.1^{\mathrm{a}}$ & 37.6 & $\pm 1.5^{\mathrm{b}}$ \\
\hline & $\%$ & 18.2 & \pm 0.6 & 18.1 & \pm 0.6 & 18.5 & \pm 0.5 & 18.4 & \pm 0.6 \\
\hline & $\%$ & 14.4 & \pm 1.1 & 15.1 & \pm 2.1 & 13.3 & $\pm 1.3^{\mathrm{a}}$ & 14.9 & $\pm 1.8^{\mathrm{b}}$ \\
\hline & $\%$ & 3.3 & \pm 0.4 & 3.2 & \pm 0.2 & 3.3 & \pm 0.3 & 3.4 & \pm 0.4 \\
\hline Empty body gain & $\mathrm{kg}$ & 13.7 & \pm 1.4 & 11.5 & \pm 1.7 & 18.0 & \pm 1.6 & 17.3 & \pm 3.4 \\
\hline \multicolumn{10}{|c|}{ As per cent of empty body gain } \\
\hline dry matter & & 38.5 & \pm 2.3 & 40.6 & \pm 5.7 & 37.7 & $\pm 2.1^{\mathrm{s}}$ & 40.5 & $\pm 3.0^{\mathrm{b}}$ \\
\hline crude protein & & 20.2 & \pm 1.2 & 20.9 & \pm 1.1 & 19.7 & \pm 0.7 & 19.7 & \pm 1.2 \\
\hline ether extract & & 14.0 & \pm 2.2 & 15.9 & \pm 5.7 & 13.3 & \pm 2.2 & 16.1 & \pm 4.0 \\
\hline crude ash & & 3.4 & \pm 0.7 & 3.3 & \pm 0.4 & 3.5 & \pm 0.5 & 3.5 & \pm 0.7 \\
\hline
\end{tabular}

composition of the empty body and empty body gain of lambs from groups $\mathrm{C}$ and $\mathrm{L}$ in both experiments did not differ (Table 9). Only a tendency towards a higher percentage of ether extract in the empty body weight and empty body gain was found in lambs from group L. The protein content in the empty body weight of group $C$ and $L$ was similar and equalled respectively 18.2 and $18.1 \%$ in experiment $I$ and 18.5 and $18.4 \%$ in experiment II. No greater differences were found in the daily deposition of energy $(1.71 ; 1.65 ; 1.82 ; 1.83 \mathrm{MJ}$ in groups $\mathrm{C}$, $\mathrm{L}$ - experiment I and C, L - experiment II, respectively). The utilization of metabolizable energy for its deposition in gain equalled to $15-16 \%$ in experiment I and $17-19 \%$ in experiment II and was by 9.3 to $13.3 \%$ better in groups $\mathrm{L}$ than $\mathrm{C}$ in both experiments. Similarly, net protein utilization was better in experiment II ( 22.7 and $25.4 \%$ in groups $\mathrm{C}$ and $\mathrm{L})$ than in experiment $\mathrm{I}(17.6$ and $20.9 \%$ in groups $\mathrm{C}$ and $\mathrm{L}$, respectively). The utilization of metabolizable energy available for growth $\left(\mathrm{K}_{\mathrm{f}}\right)$ was: 0.27 and 0.32 in experiment $I$ and 0.33 and 0.43 in experiment II, in groups $\mathrm{C}$ and $\mathrm{L}$, respectively.

\section{DISCUSSION}

The results of these experiments indicate that Polish Lowland lambs achieve daily gains of about $230-240 \mathrm{~g}$ during fattening period to about $38-40 \mathrm{~kg}$ when fed diets containing 14-15\% crude protein in DM. Merino lambs gained about $180 \mathrm{~g}$ daily, regardless of the protein level in the diet, when the protein level did 
not fall below 14\% in DM of the ration (Jayaprakash, 1984; Żebrowska et al., 1992). The utilization of protein per $1 \mathrm{~kg}$ gain by Polish Lowland lambs fed diets containing $16-18 \%$ crude protein was worse of about $14 \%$ than by lambs received diets with lower protein content, which supports results obtained for Polish Merino lambs (Żebrowska et al., 1992). This was caused by the greater nitrogen losses from the rumen, as indicated by the higher rumen ammonia level in group $\mathrm{C}$ (Table 6). The amount of nitrogen passing to the duodenum was lower in lambs from group $\mathrm{C}$ than $\mathrm{L}$ ( $91.5 \mathrm{vs} 101.6 \%$ of $\mathrm{N}$ ingested). As the result of this, the daily amount of nitrogen passing to the duodenum was equal in both groups, regardless of the amount of nitrogen intake (Table 5). In light of the similar nitrogen digestibility in the small intestine and whole digestive tract of lambs from both groups it can be assumed that the amount of nitrogen (amino acids) absorbed and available for synthesis of structural proteins was similar in both groups, what is in accordance with the lack of difference in body gain. In earlier experiment Żebrowska et al. (1992) found that when diets with a similar protein content as that in groups $\mathrm{C}$ and $\mathrm{L}$ were given, the nitrogen flow to the duodenum was higher than its intake by $12 \%$ and $20 \%$, respectively; this is in agreement with the results of Bunting et al. (1987).

Better net protein utilization (by about 19 and $12 \%$ ) and especially better metabolizable energy utilization for growth $\left(\mathrm{K}_{\mathrm{f}}-\right.$ by about 22 and $30 \%$ in experiments I and II, respectively) in the $\mathrm{L}$ groups could also have been the result of a smaller metabolizable energy to crude protein ratio; it equalled 61.7 and 70.7 in experiment $I$ and 67.2 and $73.8 \mathrm{~kJ} / \mathrm{g}$ in experiment $\mathrm{II}$ in groups $\mathrm{C}$ and $\mathrm{L}$, respectively. The poorest energy utilization $\left(K_{f}=0.27\right)$ was found when the ration contained $61.7 \mathrm{~kJ}$ metabolizable energy per gram of crude protein, while the best $\left(\mathrm{K}_{\mathrm{f}}=0.43\right)$ was at a ratio of $73.8 \mathrm{~kJ} / \mathrm{g}$. Urbaniak (1986) found similar energy utilization by fattening Merino lambs fed a ration containing $14 \%$ crude protein, while Alam et al. (1991) much worse utilization $(0.22)$ by Dorset Down $\times$ Coopworth lambs.

In both experiments the lambs ate about $80 \%$ of the amount of dry matter and from 72 to $94 \%$ of the crude protein as recommended by Polish feeding standards. The studies of Potkański et al. (1990) also show that Polish Lowland lambs did not eat all of the recommended amounts of dry matter. Comparison of the amount of protein intake which was digestible in the intestine with INRA recommendations (1989) shows that the PDI was exceeded in all of the groups by at least $5 \%$ (Table 4 ).

Feeding diet $\mathrm{L}$ to lambs did only slightly affect the results of slaughter analysis. In comparison with lambs fed diet $\mathrm{C}$ a higher separable fat content was found (Table 8), which could be related to their slower growth rate (Glimp and Snowder, 1989). As in previous studies (Pająk et al., 1992), a tendency for lower wool production was observed in lambs from group L. These results confirm 
those of Urbaniak (1986) who demonstrated a linear increase in wool production in Polish Merino lambs in response to increase of crude protein content from 9 to $16 \%$ of DM. The fatness of the carcasses was similar to that of Merino lambs slaughtered at a similar weight.

There is no data on body composition of the Polish Lowland sheep, whereas the data of the body composition of Polish Merino lambs (Borys et al., 1986; Korman et al., 1986; Pająk et al., 1992; Pakulski and Osikowski, 1986; Urbaniak, 1986) report a higher content of separable fat than attained in the experiments reported here. In both experiments a similar total protein content in empty body weight was found, 18.1 to $18.5 \%$, with a very small differences within group (SD $\pm 0.5-0.6 \%$ ). This phenomenon has been confirmed in numerous studies (Blaxter et al., 1982; Fix et al., 1988; Searle et al., 1982; Urbaniak, 1986) which showed that in spite of significant differences in the body fat content, there are no experimental factors affecting the empty body protein content. The reported values differed among these authors, but within their experiments it did not differ among groups, regardless of the experimental factors.

\section{CONCLUSIONS}

The results obtained in this study show that the reduction of protein level in the diet from about 18 to $15 \%$ (as recommended by Polish feeding standards) to $14 \%$ in dry matter did not decrease liveweight gain but significantly improved utilization of dietary protein and of metabolizable energy available for growth. An unfavourable effect is the tendency to increase the carcass fat content and a slight decrease in greasy wool production.

\section{REFERENCES}

Alam M. R., Poppi D. P., Sykes A. R., 1991. Comparative energy and protein utilization in kids and lambs. J. agric. Sci., Camb. 117, 121-127

ARC: The Nutrient Requirements of Ruminant Livestock, 1980. Commonwealth Agric. Bureaux, London

Blaxter K. L., Fowler V. R., Gill J. C., 1982. A study of the growth of sheep to maturity. J. agric. Sci., Camb. $98,405-420$

Borys B., Dulewicz R., Orzechowska W., Osikowski M., 1986. The fattening performance and slaughter value of lambs from two-step industrial crossing of Merino ewes with highly fertile breeds rams (Friesian and Olkuska sheep) and meat breeds rams. Zesz. probl. Post. Nauk rol. 303, $299-308$

Bunting L. D., Boling J. A., MacKown C. T., Muntifering R. B., 1987. Effect of dietary protein level on nitrogen metabolism in lambs: studies using ${ }^{15} \mathrm{~N}$-nitrogen. J. Anim. Sci. 64, 855-867

Fix H. P., Brützke M., Peschke 1., Hoffmann M., 1988. Untersuchungen zum Stoff-und Energieansatz wachsender Lämmer. 2. Ergebnisse der Ausschlachtungen und Tierkörperanalysen. Arch. Anim. Nutr., Berlin 38, 327-341

Glimp H. A., Snowder G. D., 1989. Production methods to increase lean and reduce fat in lamb: a reviev. SID Res. J. 5, 18-27 
INRA: Ruminant Nutrition. Recommended Allowances and Feed Tables, 1989. Jarrige R. Ed. INRA, Paris

Jayaprakash, 1984. Influence of various sources of nitrogen in the diet on the digestibility, nitrogen metabolism, growth and carcass composition of Polish Merino lambs. Ph. D. thesis, The Kielanowski Institute of Animal Physiology and Nutrition, Jabłonna

Korman K., Musial A., Osikowski M., 1986. The fattening performance, slaughter value and meat quality of lambs from two-step crossing of Polish Merino ewes with rams of some meat breeds. Zesz. probl. Post. Nauk rol. 303, 273-285

Mehrez A. Z., Ørskov E. R., 1977. A study of the artificial fibre bag technique for determining the digestibility of foods in the rumen. J. agric. Sci., Camb. 88, 645-650

Ørskov E. R., McDonald I., 1979. The estimation of protein degradability in the rumen from incubation measurements weighted according to rate of passage. J. agric. Sci., Camb. 92, $499-503$

Pająk J., Żebrowska T., Żebrowska H., 1992. Protein content in the diet for fattening lambs. 2. The chemical and amino acid composition of the body and utilization of amino acids apparently absorbed in the small intestine. J. Anim. Feed Sci. 1, 27-36

Pakulski T., Osikowski M., 1986. Fattening performance, slaughter value and meat quality of lambs from crossing of Bulgarian Merino with Polish and German Merino. Zesz. probl. Post. Nauk rol. $303,251-261$

Potkański A., Urbaniak M., Michalak W., 1990. Semi intensive lamb fattening with high silage rations. Rocz. AR Poznań, Zoot. 39, 59-69

Searle T. W., Graham N. McC., Donelly J. B., 1982. The effect of plane of nutrition on the body composition of two breeds of weaner sheep fed a high protein diet. J. agric. Sci., Camb. 98 , $241-245$

Urbaniak M., 1986. Protein requirement of Merino lambs fattened from 20 to $40 \mathrm{~kg}$ live weight. Rocz. AR Poznań, Rozpr. nauk. No. 161

Żebrowska T., Żebrowska H., Pająk J., 1992. Protein content in the diet for fattening lambs. 1. Liveweight gain, efficiency of feed utilization and digestibility of nitrogen and amino acids in the small intestine. J. Anim. Feed Sci. 1. 15-25

\section{STRESZCZENIE}

\section{Wplyw poziomu bialka w dawce na wyniki tuczu jagniąt polskiej owcy nizinnej}

Przeprowadzono dwa doświadczenia na 212 tryczkach polskiej owcy nizinnej żywionych zgodnie $z$ krajowymi normami dawką zawierającą około $17 \%$ bialka (grupa $\mathrm{C}$ ) lub dawką o obniżonej do 14\% zawartości białka ogólnego w suchej masie (grupa L). Jagnięta zjadały około $80 \%$ przewidzianej dla nich w normach krajowych ilości suchej masy i od 72 do $94 \%$ białka ogólnego. Z porównania ilości bialka strawnego w jelicie ? normami INRA wykazano, ze we wszystkich grupach zapotrzebowanic PDI było przekroczone o 5 do $24 \%$. Ilość $\mathrm{N}$-ogólnego przechodzącego do dwunastnicy była zbliżona do ilości pobranej ( 91.5 vs $101.6 \%$ w grupach C i L, odpowiednio). Nie stwierdzono istotnych różnic w dziennych przyrostach jagniąt grup C (237 i 240 g) i L (226 i 238 g), natomiast wykorzystanie białka w grupach L było istotnie lepsze $(P \leqslant 0.01)$ niż w C $(675$ i 580 vs 770 i $662 \mathrm{~g} / \mathrm{kg}$ przyrostu, odpowiednio). Morfologiczny skład tuszy jagniąt był podobny, nieznacznie większy ( $(\mathrm{P} \leqslant 0.05)$ udział tłuszcru dysekcyjnego w tuszy stwierdzono u jagniąt grupy L ( 16.5 vs 15.2 i 16.6 vs $14.7 \mathrm{w}$ doświadczeniu I i II odpowiednio), natomiast produkcja wełny była w tej grupie nieco mniejsza niż u jagniąt grupy C. 